\title{
A Small-Scale Study on Removal of Heavy Metals from Contaminated Water Using Water Hyacinth
}

\author{
An The Huynh ${ }^{1,2}$, Yi-Ching Chen ${ }^{1, *(\mathbb{C})}$ and Bich Ngoc Thi Tran ${ }^{3}$ \\ 1 Department of Environmental Engineering, Da-Yeh University, Changhua 51591, Taiwan; anht@tdmu.edu.vn \\ 2 Department of Management Sciences, Thu Dau Mot University, Binh Duong 590000, Vietnam \\ 3 Institute of Environmental Sciences and Technology, Tra Vinh University, Tra Vinh 940000, Vietnam; \\ ngocbich@tvu.edu.vn \\ * Correspondence: yiching@mail.dyu.edu.tw; Tel.: +88-69-3910-7419
}

\section{check for}

updates

Citation: Huynh, A.T.; Chen, Y.-C.; Tran, B.N.T. A Small-Scale Study on Removal of Heavy Metals from Contaminated Water Using Water Hyacinth. Processes 2021, 9, 1802. https://doi.org/10.3390/pr9101802

\section{Academic Editors:}

Avelino Núñez-Delgado,

Zhien Zhang, Elza Bontempi,

Mario Coccia, Marco Racea and Yaoyu Zhou

Received: 7 September 2021

Accepted: 8 October 2021

Published: 11 October 2021

Publisher's Note: MDPI stays neutral with regard to jurisdictional claims in published maps and institutional affiliations.

Copyright: (c) 2021 by the authors. Licensee MDPI, Basel, Switzerland. This article is an open access article distributed under the terms and conditions of the Creative Commons Attribution (CC BY) license (https:// creativecommons.org/licenses/by/ $4.0 /)$.

\begin{abstract}
The aim of this research was to determine whether water hyacinth can be used to remove heavy metals, such as cadmium, arsenic, lead, zinc, and copper, from industrial wastewater. Investigations of the pollution removal or prevention potential of aquatic macrophytes, such as heavy metal bio-indicators in aquatic habitats, can prove to be advanced field studies. Water hyacinth is one of the aquatic plant species that has been effectively utilized for the treatment of wastewater. It is extremely effective in removing stains, suspended solids, BOD, organic matter, and heavy metals. This research focused on the use of water hyacinth to treat wastewater from heavy metals. Water hyacinths can grow in sewage, absorbing and digesting contaminants and transforming sewage effluents into comparatively clean water in the process. As a result, the plants have the potential to be used as natural water purification systems at a fraction of the cost of a standard sewage treatment facility. The experiment was performed using healthy, young, and acclimatized water hyacinths. Containment water with a cadmium concentration of $0.5 \mathrm{mg} / \mathrm{L}$, arsenic concentration of $0.5 \mathrm{mg} / \mathrm{L}$, lead concentration of $2 \mathrm{mg} / \mathrm{L}$, zinc concentration of $5 \mathrm{mg} / \mathrm{L}$, and copper concentration of $5 \mathrm{mg} / \mathrm{L}$ was added to five different polyethylene pots with $100 \mathrm{~g}$ of water hyacinth in each pot. After 30 days, the removal efficiency for heavy metals $(\mathrm{Cd}, \mathrm{As}, \mathrm{Pb}, \mathrm{Zn}$, and $\mathrm{Cu}$ ) reached 59-92\%, and the results were within the permitted limits according to the National Technical Regulation on Industrial Wastewater in Vietnam. Based on this information, it is possible to deduce that water hyacinth can be utilized to remove cadmium, arsenic, lead, zinc, and copper from industrial wastewater effluents efficiently.
\end{abstract}

Keywords: heavy metals; water hyacinth; cadmium; arsenic; lead; zinc; copper

\section{Introduction}

Water pollution is a burning problem for developing countries. As societies grow, the amount of domestic and industrial waste also increases exponentially. Amounts of waste are increasing but the centralized treatment systems are not enough to deal with them along with unconcentrated discharge habits, which have caused extremely serious water pollution. In particular, heavy metal pollution involving cadmium (Cd), arsenic (As), lead $(\mathrm{Pb})$, zinc $(\mathrm{Zn})$, and copper $(\mathrm{Cu})$ is a serious problem due to the particularly dangerous toxicity of these elements affecting human health, organisms, and the environment [1].

Traditional methods, including physical and chemical processes used to treat heavy metals, are being applied, most of which have complex processes, are quite expensive in terms of economics, and have high technical requirements [2]. A study on removing arsenic contamination in soil by phytoremediation has been published [3]. Additionally, wastewater treatment using aquatic plants has been applied in many parts of the world, which has the advantages of low costs, easy operation, and high pollution treatment level [4-6]. This is a technology for the treatment of wastewater in natural and environmentally friendly conditions while increasing biodiversity and improving the landscape, environment, and local ecosystems [7]. 
The popular application of water hyacinth (Eichhornia crassipes) for wastewater treatment has gained worldwide acclaim [8]. Several metals have extraordinarily high attraction and accretion capacities for water hyacinths $[9,10]$. A typical marshland colonized by water hyacinth can act, in a way, as "nature's kidney" for proper wastewater treatment, preserving the earth's valuable water resources [8]. Water hyacinth has gained much attention for its capacity to be cultivated in extremely polluted water, in addition to its tendency to accumulate metal ions [11]. Water scarcity is becoming more prevalent around the biosphere and in numerous countries it might be unavoidable by the end of the year. With the realization that surface water contamination is a worldwide problem, the situation becomes much more alarming. Several methods for sustainable water resource utilization have been developed to solve this problem, with wastewater recovery and reuse currently being one of the most important targets. The two most common anthropogenic sources of metal in aquatic ecosystems, according to research, are domestic and industrial waste [12]. Heavy metals in water can be dangerous even in small quantities. Since the beginning of the industrial revolution, hazardous metal contamination in the biosphere has increased drastically. Water hyacinth is an aquatic plant that can effectively remove a variety of pollutants from water, making it important in wastewater treatment $[4,5]$.

Water hyacinth is a major material in the handicrafts industry in Vietnam. It is cheap and commonly planted. Furthermore, water hyacinth can be a good tool for the removal of heavy metal contamination through phytoremediation technology. For economic reasons, the use of water hyacinth in wastewater treatment should be promoted in Vietnam. In addition, water hyacinth is also used in Vietnam as fodder for livestock, compost for mushrooms, and manure. Dried water hyacinth can be processed for use in braided ropes, weaving mats, crafts, or furniture. Therefore, this study was conducted to evaluate the ability of water hyacinth to absorb heavy metals $(\mathrm{Pb}, \mathrm{Cd}, \mathrm{Zn}, \mathrm{Cu}, \mathrm{As})$ from wastewater. The results indicated good performance in the reduction of concentrations of heavy metals. The removal efficiency for heavy metals $(\mathrm{Cd}, \mathrm{As}, \mathrm{Pb}, \mathrm{Zn}$, and $\mathrm{Cu}$ ) reached $59-92 \%$ after 30 days, notably for $\mathrm{Pb}$, which was reduced by $92.4 \%$.

\section{Characteristics of Water Hyacinth}

\subsection{Water Hyacinth}

Water hyacinth is a rapidly growing, floating aquatic plant from the South American Amazon Bay [13]. It is well-known for its propensity to multiply, with the plant's population being able to double in just 12 days. Its propensity to flourish in severely contaminated waters is also well-known. As an aquatic plant capable of improving oxidation pond effluent quality and a key factor for single, integrated, and advanced treatment systems for urban, agricultural, and industrial waste streams, water hyacinth has been intensively explored. Beside wastewater treatment, water hyacinth can also be used in valuable products like biogas, bioethanol, biohydrogen, biofertilizers, and fish feed [14].

\subsection{Ecological Factors}

The ability of ecological technology to recover and reuse resources is an environmentally friendly feature. In aquatic ecosystems, for example, nutrients from phosphorous and nitrogenous wastewater components are recycled into usable biomass via ecological food chains. Warm, nutrient-rich water is ideal for water hyacinth growth. The ideal $\mathrm{H}^{+}$ion potential for this aquatic plant's growth is neutral; however, it can potentially withstand hydrogen values ranging from 4 to 10 . Water hyacinth can be used to treat a variety of types of wastewater thanks to this key feature. The ideal water temperature for growth is between $28^{\circ} \mathrm{C}$ and $30^{\circ} \mathrm{C}$. Temperatures exceeding $33^{\circ} \mathrm{C}$ stifle further development. The ideal air temperature is between $21^{\circ} \mathrm{C}$ and $30^{\circ} \mathrm{C}$. Water hyacinth can also thrive in both nutrientrich and nutrient-poor water, as well as in water that has been heavily contaminated with diverse biological and inorganic industrialized effluents containing metal ions [15-17]. Water hyacinth is a common and prolific plant that is free-floating, highly tolerant of harsh settings, and capable of rapid vegetative reproduction and survival in a variety of environ- 
ments. The maximum reproductive rate is $54.4 \mathrm{~g}$ dry weight $/ \mathrm{m}^{2} /$ day $[15,16]$. Plants grow more quickly in the summer, covering $15 \%$ more surface area every day.

\subsection{Socio-Economic Potential of Water Hyacinth in Vietnam}

Water hyacinths were introduced into Vietnam around 1905 and developed throughout the Southern Rivers on inland canals, affecting agricultural production, waterway traffic, and drainage [18]. Water hyacinths also hinder fishing and seriously affect water supply. They grow rapidly in the rainy season, and they are the residences of mosquitoes and disease-causing insects. Water hyacinth seems useless but it is considered a valuable and precious raw material for handicrafts and a "new discovery of the 21st century" because it has been exploited and used since the flood season in 2000. Recently, people in the area of the Mekong Delta have been interested in handicraft products made from this plant. Furthermore, according to the statistics of the General Department of Vietnam Customs (GDVNC), these products are also exported to foreign countries to meet the needs of fastidious markets such as those of the US, China, Japan, Europe, and South Korea, [19].

Thanks to this handicraft industry, many localities have solved unemployment problems and helped farmers increase their incomes, contributing to the eradication of hunger and poverty reduction. Since 2000, water hyacinth knitting has developed strongly in the Mekong Delta, especially in the provinces of Dong Thap, Long An, An Giang, and Vinh Long, and the development of this profession has created more jobs and increased income for farming households. Therefore, water hyacinth is also heavily exploited to provide raw materials for production.

\subsection{Mechanism of Wastewater Treatment Using Water Hyacinth}

Contaminants and stockpiles can be found in water hyacinth biomass. As they store pollutants in their tissues, these plants are known as bioaccumulators. They have a high tolerance for pollutants such as heavy metals and may absorb significant quantities of them. Phytoextraction is a technique for the removal of heavy metals from contaminated water sources [20]. The routes for pollutant uptake are described below.

Root absorption: The roots absorb contaminants in the aquatic environment. A large cation change throughout the cell membrane is caused by the presence of carboxyl groups in the root system. This acts as a mechanism for heavy metal transport within the root system, where active absorption takes place. Aerobic bacteria develop well in the water systems due to the root structures of water hyacinths (as well as other aquatic floras). Aerobic bacteria acquire nutrients and harvest inorganic compounds, which plants consume as nourishment. The plants improve rapidly and can be collected as rich and profitable fertilizer.

Foliar absorption: In addition to root absorption, foliar absorption can provide plants with small amounts of some pollutants. They are absorbed passively by stoma cells and cuticle fissures.

In this type of absorption, fibrous or feathery roots are trapped in floating particles and germs as bacterial and fungal growth attachment points. Pollutants on the root surface are absorbed by the bacteria that live on it. An ionic imbalance throughout the cell membrane also occurs.

\section{Methods}

\subsection{Instruments}

The instruments used in the study included a micropipette (Eppendorf, Hamburg, Germany), flask, test tube, electric stove, and an analytical balance from Adam (UK) with an accuracy of $0.0001 \mathrm{mg}$.

ICP-MS equipment (Perkin Elmer, Waltham, MA, USA, ELAN 9000) was used to analyze samples with the following parameters: RF power: $1000(\mathrm{~W})$; sample injector (Perkin Elmer, Waltham, MA, USA): 26 (rpm); auxiliary gas (Perkin Elmer, Waltham, MA, USA): 2 (L/min); plasma gas (Perkin Elmer, Waltham, MA, USA): 0.85 (L/min); nebulizer gas (Perkin Elmer, Waltham, MA, USA): 2.4 (L/min). 


\subsection{Chemicals}

Standard solutions of cadmium, arsenic, lead, copper, and zinc were prepared in a standard solution of $100 \mu \mathrm{g} / \mathrm{mL}$.

The chemicals used were all pure chemicals manufactured by Merck Chemical (Darmstadt, Germany). The solutions were prepared with double-distilled water.

\subsection{Analysis Sample}

The sample collection and processing period started on 20 May 2021. After being planted, the sample was monitored and the heavy metal content in the water was analyzed three times, after 10,20, and 30 days, to observe the metal content in water treated with water hyacinth over time. The heavy metals $(\mathrm{Cd}, \mathrm{As}, \mathrm{Pb}, \mathrm{Zn}$, and $\mathrm{Cu})$ in the plants were determined using inductively coupled plasma-mass spectrometry.

\subsection{Experimental Setup}

The experiments lasted 30 days and $100 \mathrm{~g}$ of water hyacinth was used in the pot. For planting, 30-L foam containers were used, which were washed of dust and soil with distilled water beforehand. The plants were fixed with stones (inexpensive, poorly absorbing substrates). Concentration selection experiments were undertaken based on the permitted threshold levels for $\mathrm{Cd}, \mathrm{As}, \mathrm{Pb}, \mathrm{Zn}$, and $\mathrm{Cu}$ in water environments according to the QCVN 40:2011/BTNMT National Technical Regulation on Industrial Wastewater in Vietnam. The experimental concentration was three to five times higher than the allowable threshold. Water hyacinth was grown in irrigation water containing the heavy metals $\mathrm{Cd}, \mathrm{As}, \mathrm{Pb}, \mathrm{Zn}$, and $\mathrm{Cu}$ according to selected concentrations:

1. Plant water containing $0.5 \mathrm{mg} / \mathrm{L}$ of $\mathrm{Cd}$ (II);

2. Plant water containing $0.5 \mathrm{mg} / \mathrm{L}$ of As (III);

3. Plant water containing $2 \mathrm{mg} / \mathrm{L}$ of $\mathrm{Pb}$ (II);

4. Plant water containing $5 \mathrm{mg} / \mathrm{L}$ of $\mathrm{Zn}$ (II);

5. Plant water containing $5 \mathrm{mg} / \mathrm{L}$ of $\mathrm{Cu}$ (II).

As a matching plant control sample, plants were planted in distilled water with stone media.

The analytical parameters were $\mathrm{Cd}, \mathrm{As}, \mathrm{Pb}, \mathrm{Zn}$, and $\mathrm{Cu}$ in water.

\subsection{Water Properties}

When simplifying the natural environment, the possibility of the accumulation of heavy metals in the plants had to be taken into consideration whilst at the same time ensuring the accuracy of the experiment. The water composition helped us to identify the nutrient content and determine whether additional nutrients had to be added to the plants [21]. Further, the metal content in the water was also an aspect that we were interested in. Identifying the presence of metal ions and the amount of accumulation helped us to assess whether there was competition for these metal ions in the accumulation in the plants and to identify the research plant that could handle $\mathrm{Cd}, \mathrm{As}, \mathrm{Pb}, \mathrm{Zn}$, and $\mathrm{Cu}$ metal ions [2]. The water samples were collected in Phu Giao district, Binh Duong, Vietnam, and the levels of water quality are listed in Table 1.

Based on the results of the water quality analysis shown in Table 1 and the Vietnam National Technical Regulation QCVN 08-MT:2015/BTNMT (Column B1), the parameters for water quality and other heavy metals content were within the allowable thresholds of the national standards. The appropriate quantities of nutrients and mineral ions required for proper plant development were used and there were no metal elements that could obstruct the accumulating process. As a result, the uptake of the tested elements should have been faster. 
Table 1. Results of water quality analysis.

\begin{tabular}{|c|c|c|c|c|}
\hline No. & Parameters & Unit & Content & $\begin{array}{c}\text { QCVN 08- } \\
\text { MT:2015/BTNMT } \\
\text { (Column B1) }\end{array}$ \\
\hline 1 & Temperature & ${ }^{\circ} \mathrm{C}$ & 25.1 & - \\
\hline 2 & $\mathrm{pH}$ & - & 6.7 & $5.5-9$ \\
\hline 3 & EC & $\mu \mathrm{S} / \mathrm{cm}$ & 58 & - \\
\hline 4 & DO & $\mathrm{mg} / \mathrm{L}$ & 8.77 & $\geq 4$ \\
\hline 5 & TDS & $\mathrm{mg} / \mathrm{L}$ & 27 & - \\
\hline 6 & $\mathrm{BOD}_{5}$ & $\mathrm{mg} / \mathrm{L}$ & 12.2 & 15 \\
\hline 7 & COD & $\mathrm{mg} / \mathrm{L}$ & 23.3 & 30 \\
\hline 8 & TSS & $\mathrm{mg} / \mathrm{L}$ & 7.3 & 50 \\
\hline 9 & As & $\mathrm{mg} / \mathrm{L}$ & $<0.005$ & 0.05 \\
\hline 10 & $\mathrm{Cd}$ & $\mathrm{mg} / \mathrm{L}$ & $<0.0005$ & 0.01 \\
\hline 11 & $\mathrm{~Pb}$ & $\mathrm{mg} / \mathrm{L}$ & $<0.005$ & 0.05 \\
\hline 12 & $\mathrm{Cr}$ & $\mathrm{mg} / \mathrm{L}$ & $<0.005$ & 0.04 \\
\hline 13 & $\mathrm{Hg}$ & $\mathrm{mg} / \mathrm{L}$ & $<0.0005$ & 0.001 \\
\hline 14 & $\mathrm{Zn}$ & $\mathrm{mg} / \mathrm{L}$ & 0.051 & 1.5 \\
\hline 15 & Mn & $\mathrm{mg} / \mathrm{L}$ & 0.158 & 0.5 \\
\hline 16 & $\mathrm{Fe}$ & $\mathrm{mg} / \mathrm{L}$ & 0.772 & 1.5 \\
\hline 17 & Total nitrogen & $\mathrm{mg} / \mathrm{L}$ & 2.92 & - \\
\hline 18 & $\mathrm{~N}-\mathrm{NO}_{3}^{-}$ & $\mathrm{mg} / \mathrm{L}$ & 0.97 & 10 \\
\hline 19 & $\mathrm{~N}-\mathrm{NO}_{2}^{-}$ & $\mathrm{mg} / \mathrm{L}$ & $<0.005$ & 0.05 \\
\hline 20 & $\mathrm{~N}-\mathrm{NH}_{4}{ }^{+} / \mathrm{NH}_{3}$ & $\mathrm{mg} / \mathrm{L}$ & $<0.006$ & 0.9 \\
\hline 21 & Total phosphorus & $\mathrm{mg} / \mathrm{L}$ & $<0.05$ & - \\
\hline 22 & $\mathrm{P}-\mathrm{PO}_{4}{ }^{3-}$ & $\mathrm{mg} / \mathrm{L}$ & $<0.05$ & 0.3 \\
\hline 23 & $S^{2-}$ & $\mathrm{mg} / \mathrm{L}$ & $<0.04$ & - \\
\hline 24 & $\mathrm{CN}^{-}$ & $\mathrm{mg} / \mathrm{L}$ & - & 0.05 \\
\hline 25 & Coliform & $\mathrm{MPN} / 100 \mathrm{~mL}$ & 1600 & 7500 \\
\hline
\end{tabular}

\subsection{Data Analysis}

The analyzed data were assessed and compared with the current QCVN 40:2011/BTNMT Vietnamese standards. The data were processed using Excel and Statgraphics software.

\section{Results and Discussions}

\subsection{The Height Growth of Water Hyacinth after 30 Days}

By definition, plant growth is associated with the process of increasing the mass, height, and size of cells or cell organelles. Growth can also represent the development and reproduction of a plant [22]. Height is one of the important indicators for assessing the growth of plants containing different environmental heavy metals $(\mathrm{Cd}, \mathrm{As}, \mathrm{Pb}, \mathrm{Zn}$, and $\mathrm{Cu}$ ). In addition to the dependence of height on the genetic characteristics of a variety, it also depends on external conditions such as climate, temperature, oxygen, mineral nutrition, fertilizer, water, etc. [23]. The growth of plants in polluted water is important for the absorption and accumulation of heavy metals in plants. The height results for the water hyacinths are presented in Table 2. There was a significant difference in height growth for these samples with $p<0.05$, which could validly explain their differences in plant growth.

Table 2. Effects of heavy metal concentrations on the height growth of water hyacinths after 30 days.

\begin{tabular}{ccc}
\hline Element & Original Height(cm) & Height after 30 Days $(\mathbf{c m})$ \\
\hline $\mathrm{Cd}$ & 43 & $44.0^{\mathrm{a}} \pm 0.5$ \\
$\mathrm{As}$ & 43 & $44.3^{\mathrm{ab}} \pm 0.5$ \\
$\mathrm{~Pb}$ & 43 & $45.7^{\mathrm{bc}} \pm 0.8$ \\
$\mathrm{Zn}$ & 43 & $46.3^{\mathrm{c}} \pm 1.5$ \\
$\mathrm{Cu}$ & 43 & $46.7^{\mathrm{c}} \pm 0.6$ \\
\hline
\end{tabular}

(1) a, b, and c represent statistically different values. (2) * means significant with $p<0.05$. 
The results in Table 2 show that the height growth rate of the water hyacinths depended on the absorption capacity of the plants. The decreasing height corresponded to the heavy metals contained in the water in the order $\mathrm{Cu}>\mathrm{Zn}>\mathrm{Pb}>\mathrm{As}>\mathrm{Cd}$. The growth condition can be described as follows:

- Plant growth in water environment with $0.5 \mathrm{mg} / \mathrm{L} \mathrm{Cd}$ and As content. Water hyacinth showed good growth signs, strong and green stems and leaves. The height did not change much;

- Plant growth in a water environment contaminated with $\mathrm{Pb}$ continued after 30 days; however, the stems and leaves had yellowed, and some stems and leaves were wilted;

- The plants in water with a $\mathrm{Zn}$ concentration of $5 \mathrm{mg} / \mathrm{L}$ grew well, increasing in height and standing strong, but in the last days of the cycle, some leaves were wilted and yellowed;

- The plants in water with $5 \mathrm{mg} / \mathrm{L}$ of $\mathrm{Cu}$ showed good growth: there was an increase in height in some of the canopies and the appearance of extra branches in young trees, lush green stems, and leaves.

The height of the water hyacinth in each pot was considered as height growth. As water hyacinth is a wild plant, it grows very well under natural conditions [24]. However, the height growth of the water hyacinths differed depending on the different metals; some plants even withered, died, and did not develop young plants. The biomass of the pot was then significantly reduced.

\subsection{The Ability of Water Hyacinth to Accumulate Heavy Metals}

Phytoremediation refers to the use of plants to partially or substantially remediate selected contaminants in contaminated soil, sludge, sediment, groundwater, surface water, and wastewater [25]. Phytoremediation is popular because of its cost-effectiveness, aesthetic advantages, and long-term applicability [26].

The objective of utilizing water hyacinth in phytoremediation technique testing was to assess its efficiency for heavy metal treatment. Therefore, after being planted, the sample was monitored and the heavy metal content in the water was analyzed three times, after 10,20 , and 30 days, to observe the metal content in water treated with water hyacinth over time. The results are presented in Table 3.

Table 3. The concentrations of heavy metals in water treated with water hyacinth over time.

\begin{tabular}{|c|c|c|c|c|c|c|c|c|c|c|c|c|c|c|c|}
\hline \multirow[b]{2}{*}{ Days } & \multicolumn{3}{|c|}{ Cadmium (Cd) Concentration } & \multicolumn{3}{|c|}{ Arsenic (As) Concentration } & \multicolumn{3}{|c|}{ Lead $(\mathrm{Pb})$ Concentration } & \multicolumn{3}{|c|}{ Zinc (Zn) Concentration } & \multicolumn{3}{|c|}{ Copper (Cu) Concentration } \\
\hline & $\mathrm{Cd}(\mathrm{mg} / \mathrm{L})$ & $\begin{array}{l}\mathrm{CV} \\
(\%)\end{array}$ & $\begin{array}{c}\mathrm{H} \\
(\%)\end{array}$ & As (mg/L) & $\begin{array}{l}\mathrm{CV} \\
(\%)\end{array}$ & $\underset{(\%)}{\mathrm{H}}$ & $\mathrm{Pb}(\mathrm{mg} / \mathrm{L})$ & $\begin{array}{l}\mathrm{CV} \\
(\%)\end{array}$ & $\begin{array}{c}\mathbf{H} \\
(\%)\end{array}$ & $\mathrm{Zn}(\mathrm{mg} / \mathrm{L})$ & $\begin{array}{l}\mathrm{CV} \\
(\%)\end{array}$ & $\begin{array}{c}\mathbf{H} \\
(\%)\end{array}$ & $\mathrm{Cu}(\mathrm{mg} / \mathrm{L})$ & $\begin{array}{l}\text { CV } \\
(\%)\end{array}$ & $\begin{array}{c}\mathrm{H} \\
(\%)\end{array}$ \\
\hline 0 & 0.5 & & & 0.5 & & & 2 & & & 5 & & & 5 & & \\
\hline 10 & $0.406 \pm 0.0006$ & 0.14 & 18.8 & $0.394 \pm 0.0006$ & 0.15 & 21.2 & $1.498 \pm 0.001$ & 0.07 & 25.1 & $3.891 \pm 0.002$ & 0.05 & 22.2 & $3.859 \pm 0.002$ & 0.05 & 22.8 \\
\hline 20 & $0.301 \pm 0.002$ & 0.51 & 39.8 & $0.285 \pm 0.001$ & 0.35 & 43.0 & $0.618 \pm 0.002$ & 0.32 & 69.1 & $2.686 \pm 0.001$ & 0.04 & 46.3 & $2.527 \pm 0.003$ & 0.12 & 49.5 \\
\hline 30 & $0.203 \pm 0.002$ & 0.75 & 59.4 & $0.196 \pm 0.002$ & 1.02 & 60.8 & $0.153 \pm 0.005$ & 3.27 & 92.4 & $1.989 \pm 0.004$ & 0.18 & 60.2 & $1.963 \pm 0.0006$ & 0.03 & 60.7 \\
\hline $\begin{array}{c}\text { QCVN } \\
\text { 40:2011/BTNMT } \\
\text { (Column B) }\end{array}$ & \multicolumn{3}{|c|}{0.1} & \multicolumn{3}{|c|}{0.1} & \multicolumn{3}{|c|}{0.5} & \multicolumn{3}{|c|}{3} & \multicolumn{3}{|c|}{2} \\
\hline
\end{tabular}

$\mathrm{H}(\%)$ : removal efficiency percentage, CV (\%): coefficient of variation.

The results show that the ability of water hyacinth to accumulate heavy metals gradually decreased with the remaining heavy metal content in the water in the order $\mathrm{Cd}<\mathrm{Zn}<\mathrm{Cu}<\mathrm{As}<\mathrm{Pb}$. In addition, Table 3 also shows that, with regard to the experimental conditions of the sample pots, the concentrations of $\mathrm{Cd}, \mathrm{As}, \mathrm{Pb}, \mathrm{Zn}$, and $\mathrm{Cu}$ in the water decreased gradually with increasing time of treatment with water hyacinth. Specifically, the $\mathrm{Cd}, \mathrm{As}, \mathrm{Pb}, \mathrm{Zn}$, and $\mathrm{Cu}$ in the water had initial concentrations of $0.5 \mathrm{mg} / \mathrm{L}, 0.5 \mathrm{mg} / \mathrm{L}$, $2 \mathrm{mg} / \mathrm{L}, 5 \mathrm{mg} / \mathrm{L}$, and $5 \mathrm{mg} / \mathrm{L}$, respectively. Ten days after planting the water hyacinths, the concentrations of $\mathrm{Cd}, \mathrm{As}, \mathrm{Pb}, \mathrm{Zn}$, and $\mathrm{Cu}$ in the water were $0.406 \mathrm{mg} / \mathrm{L}, 0.394 \mathrm{mg} / \mathrm{L}$, $1.498 \mathrm{mg} / \mathrm{L}, 3.891 \mathrm{mg} / \mathrm{L}$, and $3.859 \mathrm{mg} / \mathrm{L}$, respectively. By day 30 of the experiment, the remining $\mathrm{Pb}$ content in the solution reached the lowest level $(0.153 \mathrm{mg} / \mathrm{L})$ compared to the 
other elements, and it was within the permitted limits according to Column B of the QCVN 40:2011/BTNMT National Technical Regulation on Industrial Wastewater in Vietnam.

The experiments on growing water hyacinths in water containing heavy metals $(\mathrm{Cd}$, $\mathrm{As}, \mathrm{Pb}, \mathrm{Zn}$, and $\mathrm{Cu}$ ) showed that this plant can still grow and develop at a certain level of pollution. The analysis results for the heavy metal content $(\mathrm{Cd}, \mathrm{As}, \mathrm{Pb}, \mathrm{Zn}$, and $\mathrm{Cu})$ in the water showed a trend of decreasing concentration over time. Thus, water hyacinth has the ability to clean water contaminated with heavy metals $(\mathrm{Cd}, \mathrm{As}, \mathrm{Pb}, \mathrm{Zn}$, and $\mathrm{Cu})$ very well.

\subsection{Removal Efficiency Percentage and Remaining Percentages of Heavy Metals in Water}

The removal efficiency percentage for the plants' ability to absorb heavy metals $(\mathrm{Cd}$, $\mathrm{As}, \mathrm{Pb}, \mathrm{Zn}$, and $\mathrm{Cu}$ ) in the water over time is shown in Table 3.

The treatment efficiencies of water hyacinth for $\mathrm{Cd}, \mathrm{As}, \mathrm{Pb}, \mathrm{Zn}$, and $\mathrm{Cu}$ over the 30 days of the experiment were $59.4 \%, 60.8 \%, 92.4 \%, 60.2 \%$, and $60.7 \%$ respectively, corresponding to the initial concentrations of $0.5 \mathrm{mg} / \mathrm{L}, 0.5 \mathrm{mg} / \mathrm{L}, 2 \mathrm{mg} / \mathrm{L}, 5 \mathrm{mg} / \mathrm{L}$, and $5 \mathrm{mg} / \mathrm{L}$. By the end of the 30-day survey period, the cleaning rates of the water hyacinths for all heavy metals $(\mathrm{Cd}, \mathrm{As}, \mathrm{Pb}, \mathrm{Zn}$, and $\mathrm{Cu}$ ) were mostly high (59-92\%).

The results show that the remaining heavy metal content in the water treated with water hyacinths decreased significantly after 30 days compared to the original concentrations. The remaining percentage of $\mathrm{Pb}$ especially was only $7.65 \%$, corresponding to an original concentration of $2 \mathrm{mg} / \mathrm{L}$.

The findings of the pot trials reveal that this plant has the potential to absorb heavy elements such as cadmium, arsenic, lead, zinc, and copper from wastewater. When the plants were added to the pots, the cadmium, arsenic, lead, zinc, and copper concentrations in the pots with the plants were significantly reduced. As a result, we can conclude that evaporation and settlement caused very little loss. The results show that water hyacinth is an effective plant capable of removing heavy metals from wastewater.

Previous bench-scale tests [27] using water hyacinth treatment for polluted river water and synthetic solutions demonstrated up to $63 \%$ removal of $\mathrm{Al}, 62 \% \mathrm{Zn}, 47 \% \mathrm{Cd}, 22 \%$ $\mathrm{Mn}$, and $23 \%$ As in just seven hours of exposure to the plant. The results demonstrated very good removal efficiency in a very short time compared with this study, which only achieved removals of $18.8 \% \mathrm{Cd}$ and $21.2 \%$ As in 10 days. Nevertheless, the initial metal concentrations were very low $(0.00623 \mathrm{mg} / \mathrm{L} \mathrm{Cd}$ and $0.00211 \mathrm{mg} / \mathrm{L} \mathrm{As})$ in the benchscale tests compared to the much higher initial metal concentrations $(0.5 \mathrm{mg} / \mathrm{L} \mathrm{Cd}$ and $0.5 \mathrm{mg} / \mathrm{L}$ As) used in this study. Additionally, a study of water hyacinth as a biosorbent has been undertaken by using dry water hyacinth biomass [28]. This study involved a test that achieved 93\% As(III) removal efficiency with 120 min shaking time and initial metal concentrations of $0.2 \mathrm{mg} / \mathrm{L}$ in solution. However, it is hard to make an objective comparison since the treatment mechanism was different to this study.

\section{Conclusions}

The efficiency of wastewater treatment for the removal of $\mathrm{Cd}, \mathrm{As}, \mathrm{Pb}, \mathrm{Zn}$, and $\mathrm{Cu}$ was assessed according to the concentrations of heavy metals in water. The elimination of contaminants from the water was quite effective when the plants were grown together. According to the results of the experiments, water hyacinth was able to reduce $\mathrm{Cd}$ concentration by $59.4 \%$, As concentration by $60.8 \%$, Pb concentration by $92.4 \%$, $\mathrm{Zn}$ concentration by $60.22 \%$, and $\mathrm{Cu}$ concentration by $60.74 \%$. The total heavy metal concentration was reduced by $66.7 \%$. This treatment system proved cost-effective because of the low installation and maintenance costs. The system could be used alone or in conjunction with other wastewater treatment systems. In conclusion, the current study revealed the viability of employing the aquatic plant Eichhornia to treat wastewater in a "sustainable" and environmentally benign manner. As this was merely a laboratory-size baseline study, more research on a larger scale is needed in the future, with a focus on phytoremediation and resource utilization. 
Author Contributions: Conceptualization, A.T.H.; methodology, A.T.H.; software, A.T.H.; Formal analysis, A.T.H. and Y.-C.C.; resources, data curation, A.T.H.; writing-original draft preparation, B.N.T.T. and A.T.H.; writing-review and editing, Y.-C.C. All authors have read and agreed to the published version of the manuscript.

Funding: This research received no external funding.

Institutional Review Board Statement: Not applicable.

Informed Consent Statement: Not applicable.

Data Availability Statement: The data presented in this study are available on request from the corresponding author. The data are not publicly available.

Conflicts of Interest: The authors declare no conflict of interest.

\section{References}

1. Zheng, N.; Wang, Q.; Zheng, D. Health risk of $\mathrm{Hg}, \mathrm{Pb}, \mathrm{Cd}, \mathrm{Zn}$, and $\mathrm{Cu}$ to the inhabitants around Huludao Zinc Plant in $\mathrm{China}$ via consumption of vegetables. Sci. Total Environ. 2007, 383, 81-89. [CrossRef]

2. Dong, T.M.H.; Hoang, T.T.T.; Dao, Q.P. Research and selection of some plants capable of absorbing heavy metals (Cr, Cu, Zn) in mud dredging of Tan Hoa-Lo Gom canal (In Vietnamese: Nghiên cứu và lựa chọn một số thực vật có khả năng hấp thu các kim loại nặng $(\mathrm{Cr}, \mathrm{Cu}, \mathrm{Zn})$ trong bùn nạo vét kênh Tân Hóa-Lò Gốm). Sci. Technol. Dev. J. 2008, 11, 59-67.

3. Le, H.Q.; Chen, Y.C.; Huynh, T.A.; Thai, V.L. A Study on Removing Arsenic Contamination in Soil by Phytoremediation. Key Eng. Mater. 2019, 818, 113-117. [CrossRef]

4. Zimmels, Y.; Kirzhner, F.; Roitman, S. Use of naturally growing aquatic plants for wastewater purification. Water Environ. Res. 2004, 76, 220-230. [CrossRef]

5. Dar, S.H.; Kumawat, D.M.; Singh, N.; Wani, K.A. Sewage Treatment Potential of Water Hyacinth (Eichhornia crassipes). Res. J. Environ. Sci. 2011, 5, 377-385. [CrossRef]

6. Vo, T.H.; Truong, P.K.D.; Tran, P.K.M.; Le, H.T.; Nguyen, M.T.; Pham, T.M.T. Survey the efficiency of domestic wastewater handling of water hyacinth and buffalo spinach (In Vietnamese: Khảo sát hiệu quả xử lý nước thải sinh hoạt của lục bình và ngổ trâu). J. Thu Dau Mot Univ. 2014, 14, 25-30.

7. Le, T.T.; Nguyen, T.M. Research on handling heavy metal pollution in water-by-Water Hyacinth (Eichhornia Crassipes) and Reed (Phragmites Australis) (In Vietnamese: Nghiên cứu sử dụng bèo tây (Eichhornia Classical) và cây sậy (Phragmites australis) xử lý nước bị ô nhiễm các kim loại nặng, cadimi $(\mathrm{Cd})$, chì $(\mathrm{Pb})$, kẽm $(\mathrm{Zn})$ và đồng $(\mathrm{Cu}))$. Sci. J. Hong Duc Univ. 2020, 5, 133-142.

8. Tchobanoglous, G.; Maitski, F.; Thoson, K.; Chadwick, T.H. Evaluation and performance of city of San Diego plot scale aquatic wastewater management system using water hyacinth. Res. J. Water Pollut. Control Fed. 1989, 61, 1625-1635.

9. Zaranyika, M.F.; Mutoko, F.; Murahwa, H. Uptake of Zn, Co, Fe and Cr by water hyacinth (Eichhorniacrassipes) in Lake Chivero, Zimbabwe. Sci. Total Environ. 1994, 153, 117-121. [CrossRef]

10. Zhu, Y.L.; Zayed, A.M.; Qian, J.H.; Souza, M.D.; Terry, N. Phytoaccumulation of trace elements by wetland plants: 11 . Water hyacinth. J. Environ. Qual. 1999, 28, 339-344. [CrossRef]

11. Anushee, M. Environmental challenge vis a vis opportunity: The case of water hyacinth. J. Environ. Qual 2005, 32, 122-138.

12. Häder, D.-P.; Banaszak, A.T.; Villafañe, V.E.; Narvarte, M.A.; González, R.A.; Helbling, E.W. Anthropogenic pollution of aquatic ecosystems: Emerging problems with global implications. Sci. Total Environ. 2020, 713. [CrossRef] [PubMed]

13. Bolenz, S.; Omran, H.; Gierschner, K. Treatments of water hyacinth tissue to obtain useful products. J. Biol. Wastes 1990, 33, 63-74. [CrossRef]

14. Dwivedi, M.; Dwivedi, A.K. Valuable Product from Water Hyacinth-Review Paper. Int. Res. J. Eng. Technol. $2018,5,838-843$.

15. Gopal, B. Water Hyacinth. Elsevier Aquat. Plant Stud. 1987, 471, 11-19.

16. Trivedy, R.K. Water hyacinth-based systems for waste treatment. Adv. Wastewater Treat. Technologies. Glob. Sci. $1998,1,463-486$.

17. Granato, M. Cyanide degradation by water hyacinths, Eichhornia crassipes (Mart) Solms. Biotechnol. Lett. 1993, 15, 1085-1090. [CrossRef]

18. Flower. Learn about Water Hyacinth (In Vietnamese: Tìm hiểu về hoa lục bình-Water Hyacinth). Available online: https: //vietflower.info/2018/tim-hieu-ve-hoa-luc-binh-water-hyacinth (accessed on 1 August 2021).

19. General Department of Vietnam Customs (GDVNC). Statistics of import and export goods (In Vietnamese: Báo cáo thống kê của Tổng cục Hải quan về các thị trường xuất khẩu sản phẩm thủ công mỹ nghệ của việt nam 2017). Vietnam 2017, 2, 1-22.

20. Garbisu, C.; Alkorta, I. Phytoextraction: A cost-effective plant-based technology for the removal of metals from the environment. Bioresour. Technol. 2001, 77, 229-236. [CrossRef]

21. Dang, D.K. Research on the use of plants to improve heavy metal contaminated soil in areas of mineral exploitation (In Vietnamese: Nghiên cứu sử dụng thực vật để cải tạo đất bị ô nhiễm kim loại nặng tại các vùng khai thác khoáng sản). J. Environ. 2011, 5, 201-207.

22. Nguyen, M.C. Plant Growth Regulators Applied in Agriculture (In Vietnamese: Các chất điều hòa sinh Trưởng Thực vật Úng Dụng Trong nông Nghiệp); Agriculture Publishing House: Hanoi, Vietnam, 2012. 
23. Bui, T.K.A. Study on the Use of Plants (Ferns) to Treat Arsenic Contamination in Soil in Mineral Mining Areas (In Vietnamese: Nghiên cứu sử dụng thực vật (dương xỉ) để xử lý ô nhiễm Asen Trong đất Vùng Khai Thác Khoáng Sản). Ph.D. Thesis, University of Natural Sciences-Vietnam National University, Hanoi, Vietnam, 2011.

24. Le, T.P.; Le, T.D. Studying on absorbing possibility of lead $\mathrm{Pb}^{+2}$ in aquatic environments of Hyacinth (In Vietnamese: Nghiên cứu hấp thụ $\mathrm{Pb}^{2+}$ trong nước của cây lục bình). Sci. J. TDMU 2016, 3, 42-49.

25. Sukha, R.V.; Srivastava, P.N. Phytoremediation-Green for Environmental Clean. Proceedings of Taal2007: The 12th World Lake Conference, Rajasthan, India, 28 October-2 November 2007; pp. 1016-1021.

26. Annette, C.D.; Jerald, L.S. Advances in Phytoremediation. Environ. Health Perspect. 2001, 109, $163-168$.

27. Jones, J.L.; Jenkins, R.O.; Haris, P.I. Extending the geographic reach of the water hyacinth plant in removal of heavy metals from a temperate Northern Hemisphere River. Sci. Rep. 2018, 8, 1-15. [CrossRef] [PubMed]

28. Al Rmalli, S.W.; Harrington, C.F.; Ayub, M.; Haris, P.I. A biomaterial based approach for arsenic removal from water. J. Environ. Monit. 2005, 7, 279-282. [CrossRef] [PubMed] 